\title{
Combined open microsurgical and endoscopic resection of hypothalamic hamartomas
}

\author{
Technical note
}

\author{
Jonathan Roth, M.D., Marian M. Bercu, M.D., M.Sc., \\ and Shlomi Constantini, M.D., M.Sc.
}

Department of Pediatric Neurosurgery, Dana Children's Hospital, Tel Aviv Sourasky Medical Center, and Tel Aviv University, Tel Aviv, Israel

\begin{abstract}
Hypothalamic hamartomas (HHs) are typically located within the vicinity of the third ventricle. They can be attached to the walls of the third ventricle, within the interpeduncular cistern (third ventricle floor), and/or attached to the mammillary bodies and hypothalamus. Depending on their location, resection is performed either through the third ventricle, approaching from above, or via a frontotemporal craniotomy (pterional or frontoorbital), approaching from below. "Above" approaches typically include the transcallosal-anterior interforniceal approach, and recently, purely endoscopic approaches performed transforaminally.

The authors present a combined open and endoscopic approach for resection of HHs located within the third ventricle. They used this approach in 2 young girls with relatively small lateral and third ventricles. Following an interhemispheric, transcallosal approach and exposure of the right foramen of Monro, an endoscope was inserted through the foramen, which enabled safe resection of the $\mathrm{HH}$.

The main advantage of the combined approach is when the lateral and third ventricles are relatively small, making a purely endoscopic approach more challenging and possibly riskier.

(http://thejns.org/doi/abs/10.3171/2013.2.PEDS12275)

\section{KEY WORDS • hypothalamic hamartoma • endoscopy • open surgery • third ventricle • foramen of Monro • technique}

$\mathrm{H}$ YPOTHALAMIC hamartomas may cause intractable seizures, typically "gelastic seizures," but also potentially various other seizure types. The "epileptic generator" is thought to arise from the $\mathrm{HH}$ itself, as demonstrated by direct intralesional recordings, and the electrical activity spreads to the adjacent limbic structures and hypothalamus. ${ }^{9,10,13}$ Seizure activity arising from $\mathrm{HH}$ may not be shown on surface EEG studies, and even when abnormal EEG activity is demonstrated on surface recordings, it may be misleading with respect to the presumed epileptic focus..$^{21}$

Hypothalamic hamartomas are almost always located either inside or under the third ventricle, in the interpeduncular cistern.?

The indication for treatment of $\mathrm{HH}$ is intractable seizures. Thus, the goal of treatment is not necessarily a total resection of the $\mathrm{HH}$, but rather disconnection from the adjacent hypothalamus and mammillary bodies. ${ }^{4-6,16,17,20}$

Focused radiation has been described for the treatment of $\mathrm{HH}$, but surgery remains the main treatment. ${ }^{1,12}$ Surgical approaches to HH vary and depend on the hamartoma's location. Recently, neuroendoscopy has gained popularity for lesions in the third ventricle., $, 4,6,15-17$ When

Abbreviations used in this paper: $\mathrm{EEG}=$ electroencephalographic; $\mathrm{HH}=$ hypothalamic hamartoma. the lateral ventricles are small, a comfortable approach may be gained with the use of navigation-coupled systems. ${ }^{8,14,17,19,22}$ However, endoscopic surgery in small ventricles is challenging and may lead to injury to the basal ganglia and related structures, especially when larger endoscopes are used. We describe a combined approachopen microsurgical and endoscopic - to maximize safety in resecting third ventricular $\mathrm{HH}$.

We present 2 cases involving young girls with refractory seizures attributed to small HHs in the third ventricle. Both patients had relatively small lateral and third ventricles, and we therefore decided not to perform a purely endoscopic approach, but rather a combined open and endoscopic approach.

\section{Illustrative Cases}

Case 1

History and Presentation. This 15-year-old girl presented with a history of seizures since the age of 5 years. These presented as uprising gastric sensation, accompanied with micropsia, staring, and clonic and tonic-clonic

This article contains some figures that are displayed in color online but in black-and-white in the print edition. 
movements of the right limbs and face. Additionally, she suffered from atonic drop attacks, opisthotonos, and mouth deviation or twitching. Over the years, there had been an escalation in the intensity and frequency of the seizures. Findings of neurological examinations performed between seizure events were normal.

Magnetic resonance imaging of the brain revealed a small $\mathrm{HH}$ within the third ventricle, adherent to the right hypothalamus (Fig. 1A). The lateral and third ventricles were relatively small. Multiple video EEG studies did not show any seizure activity. Five antiepileptic drugs had failed to control the seizures.

In 2009, the patient underwent Gamma Knife surgery to the lesion with no subsequent improvement in her complaints. She was diagnosed as having psychogenic paroxysmal dystonia.

After exhausting various medical treatments, the parents opted for surgical treatment.

Operation. Due to the small ventricles, and small foramina of Monro, a pure endoscopic approach was not chosen. However, it was estimated that performing an "open" approach to the lateral ventricle would enable a safe placement of the endoscope into the third ventricle and a more controlled lesion resection (Fig. 2).

A right interhemispheric, transcallosal approach was performed using standard navigation with the patient positioned supine and her head in neutral position. The corpus callosum was longitudinally opened for $20 \mathrm{~mm}$, and the right ventricle was entered. The choroid plexus over the foramen of Monro was coagulated, and a small foramen of about 3-4 $\mathrm{mm}$ was exposed. At this stage a $12^{\circ}$ Oi endoscope (Oi HandyPro Neuroendoscope, Karl Storz) was placed through the foramen of Monro, and the $\mathrm{HH}$ was clearly visualized adherent to the right hypothalamus (Fig. 1B). Using the endoscopic monopolar probe, the interface between the $\mathrm{HH}$ and right hypothalamus was coagulated. The lesion was removed piecemeal using endoscopic cap forceps (Video 1).

VIDEO 1. Video clip showing combined interhemispheric and endoscopic transforaminal resection of an $\mathrm{HH}$ in Case 1. Click here to view with Media Player. Click here to view with Quicktime.

Postoperative Course. Following surgery, there was a complete resolution of the seizures. Postoperative MRI showed complete resection of the lesion (Fig. 1C).

Case 2

History and Presentation. This 18-year-old girl had a history of refractory seizures since infancy. She was diagnosed as having an $\mathrm{HH}$ and underwent partial resection of the interpeduncular component at the age of 4 years. The resective surgery was followed by radiosurgery to the residual lesion.

Despite these treatments, the girl suffered multiple daily seizures, including gelastic seizures and rage attacks, and a general somnolent affect probably secondary to a near-constant postictal condition.

Brain MRI showed an HH adherent to the right hypothalamus, with an infraventricular component (Fig. 1D). The patient's lateral and third ventricles were relatively small.

Due to the failure of previous treatments we opted to proceed with surgical disconnection. Because of the small size of the ventricles, we performed a combined surgery.

Operation. The technique was similar to the above description-a right interhemispheric approach was used, followed by a transforaminal endoscopic resection of the intraventricular component of the $\mathrm{HH}$, using a $30^{\circ} \mathrm{MINOP}$ (Aesculap) endoscope. The lesion was relatively avascular, and was resected in a piecemeal manner using endoscopic cap forceps (Video 2). The infraventricular component was not resected.

VIDEO 2. Video clip showing combined interhemispheric and endoscopic transforaminal resection of an $\mathrm{HH}$ in Case 2. Click here to view with Media Player. Click here to view with Quicktime.

Postoperative Course. Following surgery, there was a complete resolution of the seizures. Postoperative MRI showed near-complete resection of the intraventricular component of the $\mathrm{HH}$.

\section{Discussion}

Hypothalamic hamartomas are almost always located either inside or under the third ventricle, in the interpeduncular cistern. ${ }^{7}$ Lesions located within the third
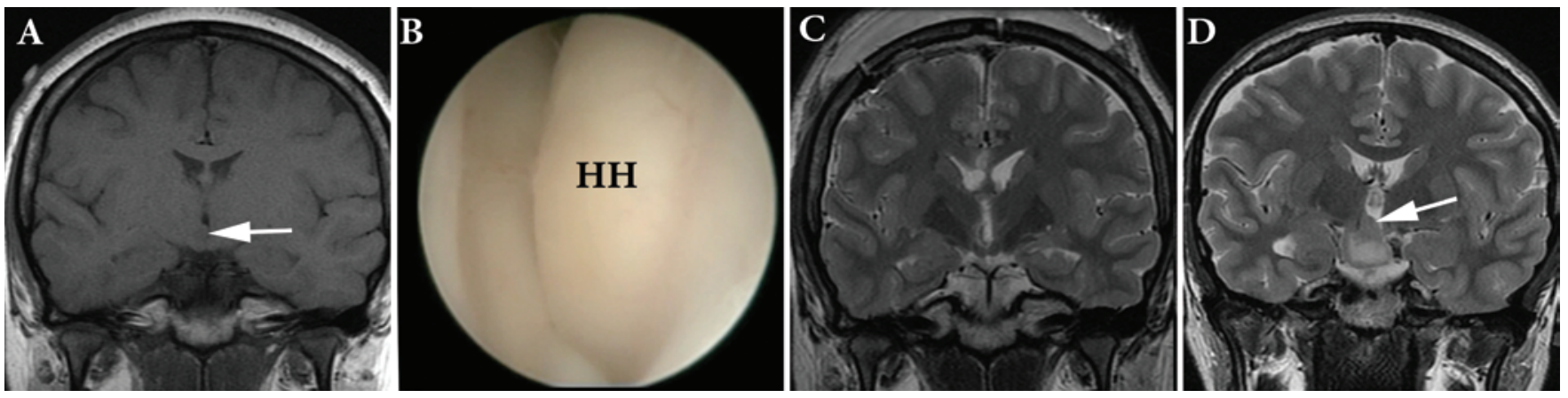

FIG. 1. A-C: Case 1. Coronal T1-weighted MR image (A) showing a small third ventricular $\mathrm{HH}$ adherent to the right hypothalamus (arrow), endoscopic view of the lesion (B), and postoperative coronal T2-weighted MR image (C) showing resection of the lesion. D: Case 2. Coronal T2-weighted MR image showing an infra- and intraventricular HH adherent to the right hypothalamus (arrow). 


\section{Combined open and endoscopic approach for hamartoma resection}

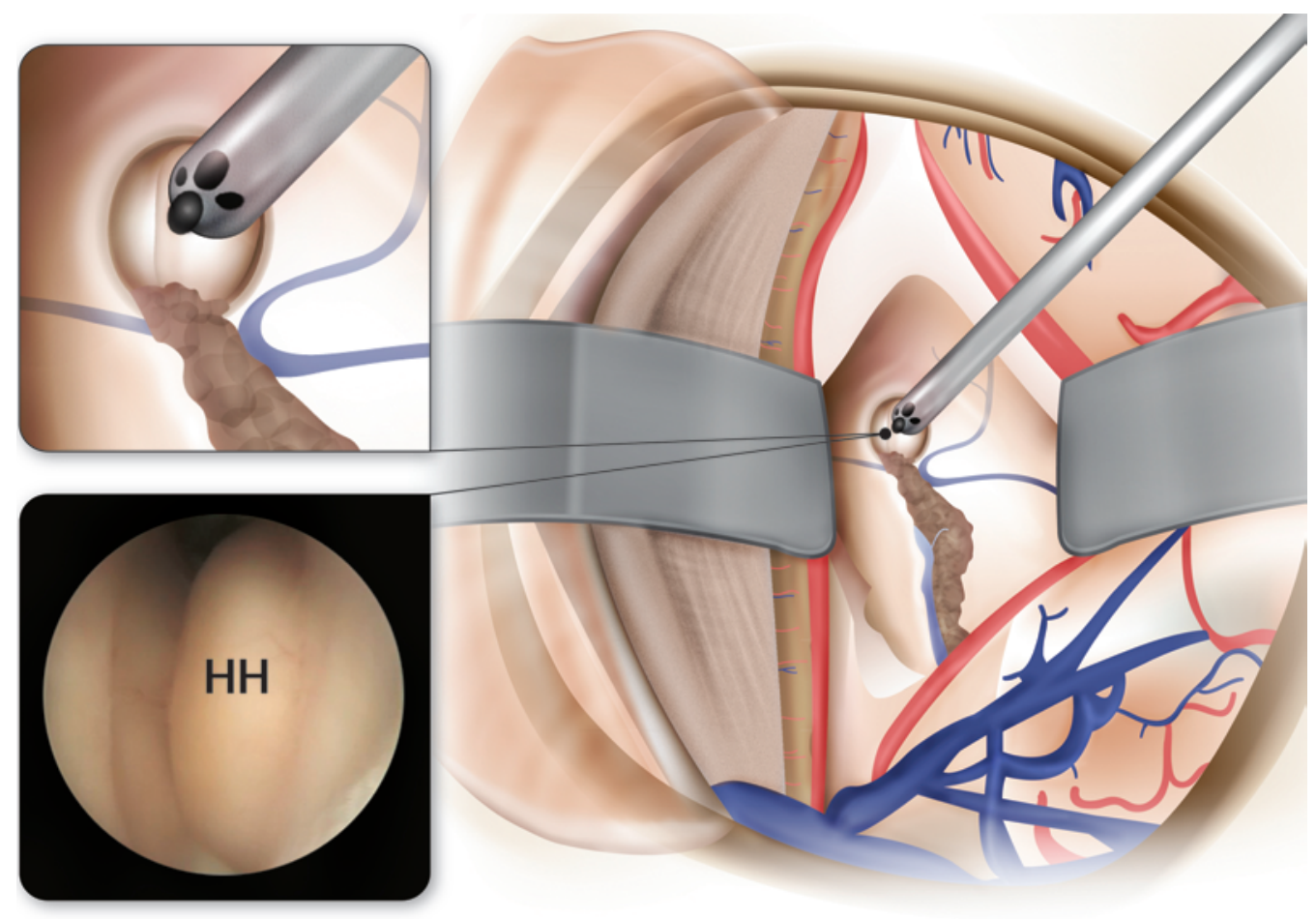

FIG. 2. Schematic sketch of the combined surgical approach with endoscopic view of an $\mathrm{HH}$.

ventricle are usually approached from "above"-through the ventricles, while those in the interpeduncular cistern, or the very anterior lesions, may be approached from "below"- through the basal cisterns. ${ }^{7}$

Most approaches in which HHs are approached from "above" are transventricular. Because of the relatively anterior location of the $\mathrm{HH}$ within the third ventricle, Rosenfeld described and perfected his transcallosal, anterior interforniceal approach. ${ }^{18}$ Over recent years, several groups have described and gained a large amount of experience in purely endoscopic approaches for resection and disconnection of HHs., , $^{4,6,15-17}$

The advantages of the transcallosal, anterior interforniceal approach are that it is an open, fully controlled, microsurgical approach; however, the distance to the third ventricle is far, the working space is small, and this approach may risk both fornices. ${ }^{18}$ In contradistinction, the pure endoscopic approach is relatively straightforward and includes stereotactically placing the endoscope transcortically into the lateral ventricle, then through the foramen of Monro, enabling a "line of sight" to the contralateral HH-hypothalamic interface. ${ }^{15}$ There are no defined ventricular dimension limits for the use of endoscopy in the current literature. Endoscopic third ventriculostomy has been described to be feasible through small ventricles. ${ }^{3}$ However, to perform an endoscopic resection, more space is required. For advanced procedures, larger endoscopes may provide better optics, the usage of bipolar coagulation, and insertion of endoscopic ultrasonic aspirators. The ventricles need to be sufficiently large to safely accommodate the endoscopic hardware, and enable passage through the foramen of Monro. Performing endoscopic surgery in small ventricles is feasible, especially when the endoscope is coupled with a navigation system and the surgeon is experienced..$^{8,14,17,19,22}$ However, it is important to emphasize that entering and working within small ventricles with a 5-6 $\mathrm{mm}$ scope may cause tissue injury even with stereotactic assistance.

In 1998 , Gaab et al ${ }^{8}$ briefly mentioned performing endoscopic resection of lesions in the trigone (a cavernoma and a hemangioma) in 2 patients with no hydrocephalus. The endoscopic technique was applied through a transcallosal approach, but the authors do not elaborate on the technique or indications for the combined approach.

The combined approach described above, enabled a straightforward approach to the lateral ventricle and foramen of Monro. Our approach differs from the endoscopic approach described by Delalande, Rekate, and others in that we entered through the right ventricle and foramen of Monro despite the lesion's being attached to the right hypothalamus. ${ }^{5,15-17}$ The reason was that in using the interhemispheric route, the working trajectory was almost vertical, in contrast to the trajectory in the endoscopic, transcortical, transventricular approach described by others. Thus we had good and nearly symmetrical control on both sides of the third ventricle. It should be noted, however, that the ipsilateral HH-hypothalamic interface could be more easily seen than that on the contralateral side. Thus, in a left-sided $\mathrm{HH}$, a left interhemispheric approach (also through the left foramen of Monro) would be preferred.

Using a small endoscope enables a safe entry though the narrow foramen of Monro relative to a microsurgical transforaminal approach. The use of a small-diameter endoscope (up to $6 \mathrm{~mm}$ ) prevented us from using the endoscopic CUSA (Cavitron ultrasonic surgical aspirator) described by Rekate et al., ${ }^{11}$ but monopolar disconnection 
and piecemeal resection were easily achieved. It is important to note that HHs are relatively avascular and may be resected with minimal cautery, thus avoiding the risk of thermal injury to the hypothalamus.

\section{Conclusions}

Combined open and endoscopic resection of third ventricular $\mathrm{HH}$ may be a safe and preferred technique in patients with small HHs and small ventricles.

\section{Disclosure}

The authors report no conflict of interest concerning the materials or methods used in this study or the findings specified in this paper.

Author contributions to the study and manuscript preparation include the following. Conception and design: Roth, Constantini. Acquisition of data: Roth, Bercu. Drafting the article: Roth. Critically revising the article: all authors. Reviewed submitted version of manuscript: all authors. Approved the final version of the manuscript on behalf of all authors: Roth. Administrative/technical/material support: Roth. Study supervision: Roth.

\section{Acknowledgment}

The authors thank Mrs. Sigal Friedman for her assistance with editing the figures.

\section{References}

1. Abla AA, Shetter AG, Chang SW, Wait SD, Brachman DG, $\mathrm{Ng}$ YT, et al: Gamma Knife surgery for hypothalamic hamartomas and epilepsy: patient selection and outcomes. Clinical article. J Neurosurg 113 Suppl:207-214, 2010

2. Akai T, Okamoto K, Iizuka H, Kakinuma H, Nojima T: Treatments of hamartoma with neuroendoscopic surgery and stereotactic radiosurgery: a case report. Minim Invasive Neurosurg 45:235-239, 2002

3. Chernov MF, Kamikawa S, Yamane F, Ishihara S, Hori T: Neurofiberscope-guided management of slit-ventricle syndrome due to shunt placement. J Neurosurg 102 (3 Suppl):260-267, 2005

4. Choi JU, Yang KH, Kim TG, Chang JH, Chang JW, Lee BI, et al: Endoscopic disconnection for hypothalamic hamartoma with intractable seizure. Report of four cases. J Neurosurg 100 (5 Suppl Pediatrics):506-511, 2004

5. Delalande O, Fohlen M: Disconnecting surgical treatment of hypothalamic hamartoma in children and adults with refractory epilepsy and proposal of a new classification. Neurol Med Chir (Tokyo) 43:61-68, 2003

6. Fohlen M, Lellouch A, Delalande O: Hypothalamic hamartoma with refractory epilepsy: surgical procedures and results in 18 patients. Epileptic Disord 5:267-273, 2003

7. Frazier JL, Goodwin CR, Ahn ES, Jallo GI: A review on the management of epilepsy associated with hypothalamic hamartomas. Childs Nerv Syst 25:423-432, 2009

8. Gaab MR, Schroeder HW: Neuroendoscopic approach to intraventricular lesions. J Neurosurg 88:496-505, 1998

9. Kahane P, Ryvlin P, Hoffmann D, Minotti L, Benabid AL: From hypothalamic hamartoma to cortex: what can be learnt from depth recordings and stimulation? Epileptic Disord 5: 205-217, 2003

10. Kuzniecky R, Guthrie B, Mountz J, Bebin M, Faught E, Gilliam F, et al: Intrinsic epileptogenesis of hypothalamic hamartomas in gelastic epilepsy. Ann Neurol 42:60-67, 1997

11. Lekovic GP, Gonzalez LF, Feiz-Erfan I, Rekate HL: Endoscopic resection of hypothalamic hamartoma using a novel vari- able aspiration tissue resector. Neurosurgery 58 (1 Suppl): ONS166-ONS169, 2006

12. Mathieu D, Deacon C, Pinard CA, Kenny B, Duval J: Gamma Knife surgery for hypothalamic hamartomas causing refractory epilepsy: preliminary results from a prospective observational study. Clinical article. J Neurosurg 113 Suppl: 215-221, 2010

13. Munari C, Kahane P, Francione S, Hoffmann D, Tassi L, Cusmai R, et al: Role of the hypothalamic hamartoma in the genesis of gelastic fits (a video-stereo-EEG study). Electroencephalogr Clin Neurophysiol 95:154-160, 1995

14. Naftel RP, Tubbs RS, Reed GT, Wellons JC III: Small ventricular access prior to rigid neuroendoscopy. Technical note. J Neurosurg Pediatr 6:325-328, 2010

15. Ng YT, Rekate HL, Prenger EC, Wang NC, Chung SS, Feiz-Erfan I, et al: Endoscopic resection of hypothalamic hamartomas for refractory symptomatic epilepsy. Neurology 70:1543-1548, 2008

16. Procaccini E, Dorfmuller G, Fohlen M, Bulteau C, Delalande $\mathrm{O}$ : Surgical management of hypothalamic hamartomas with epilepsy: the stereoendoscopic approach. Neurosurgery 59 (4 Suppl 2):ONS336-ONS346, 2006

17. Rekate HL, Feiz-Erfan I, Ng YT, Gonzalez LF, Kerrigan JF: Endoscopic surgery for hypothalamic hamartomas causing medically refractory gelastic epilepsy. Childs Nerv Syst 22: $874-880,2006$

18. Rosenfeld JV, Harvey AS, Wrennall J, Zacharin M, Berkovic SF: Transcallosal resection of hypothalamic hamartomas, with control of seizures, in children with gelastic epilepsy. Neurosurgery 48:108-118, 2001

19. Souweidane MM: Endoscopic surgery for intraventricular brain tumors in patients without hydrocephalus. Neurosurgery 62 (6 Suppl 3):1042-1048, 2008

20. Squires LA, Constantini S, Miller DC, Wisoff JH: Hypothalamic hamartoma and the Pallister-Hall syndrome. Pediatr Neurosurg 22:303-308, 1995

21. Troester M, Haine-Schlagel R, Ng YT, Chapman K, Chung S, Drees $C$, et al: EEG and video-EEG seizure monitoring has limited utility in patients with hypothalamic hamartoma and epilepsy. Epilepsia 52:1137-1143, 2011

22. Yamamoto M, Oka K, Takasugi S, Hachisuka S, Miyake E, Tomonaga M: Flexible neuroendoscopy for percutaneous treatment of intraventricular lesions in the absence of hydrocephalus. Minim Invasive Neurosurg 40:139-143, 1997

Manuscript submitted May 30, 2012.

Accepted February 12, 2013.

Please include this information when citing this paper: published online March 22, 2013; DOI: 10.3171/2013.2.PEDS12275. Supplemental online information:

Video 1: http://mfile.akamai.com/21490/wmv/digitalwbc.download. akamai.com/21492/wm.digitalsource-na-regional/peds12-275_ video_1.asx (Media Player).

http://mfile.akamai.com/21488/mov/digitalwbc.download.akamai. com/21492/qt.digitalsource-global/peds12-275_video_1.mov (Quicktime).

Video 2: http://mfile.akamai.com/21490/wmv/digitalwbc.download. akamai.com/21492/wm.digitalsource-na-regional/peds 12-275_ video_2.asx (Media Player).

http://mfile.akamai.com/21488/mov/digitalwbc.download.akamai. com/21492/qt.digitalsource-global/peds12-275_video_2.mov (Quicktime).

Address correspondence to: Jonathan Roth, M.D., Department of Pediatric Neurosurgery, Dana Children's Hospital, Tel Aviv Medical Center, 6 Weizman Street, Tel Aviv 64239, Israel. email: jonaroth@ gmail.com. 